\title{
A Review of Vaccinations in Adult Patients with Secondary Immunodeficiency
}

Elda Righi (D) · Tolinda Gallo · Anna Maria Azzini · Fulvia Mazzaferri •

Maddalena Cordioli · Mara Merighi · Evelina Tacconelli

Received: May 5, 2020 / Accepted: January 20, 2021 / Published online: March 9, 2021

(C) The Author(s) 2021

\section{ABSTRACT}

Vaccine-preventable diseases and their related complications are associated with increased morbidity and mortality in patients with altered immunocompetence. Optimised immunisation in this patient population is challenging because of limited data from vaccine trials, suboptimal vaccine efficacy and safety concerns. Reliable efficacy data are lacking among patients with altered immunocompetence, and existing recommendations are mainly based on expert consensus and may vary geographically. Inactivated vaccines can be generally used without risks in this group, but their efficacy

Elda Righi and Tolinda Gallo contributed equally to the paper.

Supplementary Information The online version contains supplementary material available at https:// doi.org/10.1007/s40121-021-00404-y.

E. Righi $(\bowtie) \cdot$ A. M. Azzini · M. Cordioli ·

E. Tacconelli

Infectious Diseases, Department of Diagnostics and

Public Health, University of Verona, Verona, Italy

e-mail: elda.righi@libero.it

E. Righi - A. M. Azzini - F. Mazzaferri - M. Cordioli ·

M. Merighi · E. Tacconelli

Infectious Diseases, Verona University Hospital,

Verona, Italy

T. Gallo

Public Health Department, Azienda Sanitaria

Universitaria Friuli Centrale, Udine, Italy may be reduced, and immunisation schedules vary according to local guidelines, age, and type and stage of the underlying disease. Live vaccines, if indicated, should be administered with care because of the risk of vaccine-associated disease. We have reviewed the current evidence on vaccination principles and recommendations in adult patients with secondary immunodeficiencies, including asplenia, HIV infection, stem cell and solid organ transplant, haematological malignancies, inflammatory bowel disease and other chronic disorders.

Keywords: Altered immunocompetence; Inactivated vaccines; Live vaccines; Vaccination 


\section{Key Summary Points}

Vaccination can prevent diseases burdened by high mortality and their complications among patients with altered immunocompetence.

Limited data are available on safety and effectiveness (e.g. optimal serological response) of vaccines in patients with altered immunocompetence.

Vaccination during early course of diseases or before the onset of immunosuppression is recommended, since disease progression may further impair immunity and vaccine efficacy.

While vaccination against Streptococcus pneumoniae and influenzavirus is generally recommended in all patients with altered immunity, other vaccines should be administered according to local recommendations, age and underlying disease.

Experts in vaccination should be involved to increase vaccine coverage in patients with altered immunocompetence.

There is an urgent need for large prospective studies on vaccine efficacy in specific subsets of patients with altered immunity.

\section{DIGITAL FEATURES}

This article is published with digital features, including a summary slide, to facilitate understanding of the article. To view digital features for this article go to https://doi.org/10.6084/ m9.figshare.13607624.

\section{INTRODUCTION}

Vaccine-preventable diseases and their related complications are associated with increased morbidity and mortality [1]. Immunisations of subjects at high risk for vaccine-preventable diseases, such as patients with altered immunocompetence (AI), currently represent a public health priority [1]. Influenza and pneumococcal vaccines that may prevent lifethreatening conditions such as severe pneumonia, myocarditis, sepsis and meningoencephalitis are universally recommended in patients with AI, although this population may also require immunisations that are outside of the routine age-based recommendation (e.g. Haemophilus influenzae type b-Hib, and meningococcal vaccines) [1-12].

The ongoing severe acute respiratory syndrome coronavirus 2 (SARS-CoV-2) pandemic has generated unprecedented needs and opportunities for large-scale immunisation of fragile populations, although data on the efficacy and safety of the currently available vaccines against coronavirus disease 2019 (COVID19) for AI patients are currently not available [13]. Furthermore, although SARS-CoV-2-associated immunosuppression has been documented [14], its potential impact on bacterial or viral coinfections or long-term decreased vaccine responses among patients with $\mathrm{AI}$ is still unclear.

Clear evidence for vaccination efficacy and disease prevention among patients with AI remain scarce [2-12]. In 2013, the Infectious Diseases Society of America (IDSA) published clinical practice guidelines addressing vaccinations in immunocompromised patients [2]. Input for the guidance was provided by the CDC Advisory Committee on Immunization Practices (ACIP) and included recommendations mainly based on expert opinion because of the paucity of data available from clinical trials [2]. Furthermore, a clear definition of AI is lacking and includes heterogeneous conditions characterised by quantitative and/or qualitative deficiencies in cellular and humoral immunity with various degrees of severity. Secondary immunodeficiency is generally acquired as the consequence of an immunological, infectious or oncological disease or is caused by immunosuppressants [15]. Examples of diseases and treatments resulting in secondary immune deficiency include HIV infection, 
haematopoietic malignancies, solid tumours and treatment with radiation, chemotherapy (e.g. alkylating agents and antimetabolites), monoclonal antibodies (e.g. tumour necrosis factor alpha inhibitors) and prolonged highdose corticosteroids [15, 16]. The level of immunosuppression, however, is difficult to quantify and varies according to drug doses, targets, combination therapy and duration of immunosuppression $[15,16]$. Moreover, underlying diseases and their progression may derive from a combination of immunological deficits. Other causes of AI include conditions that may occur in otherwise healthy subjects (e.g. traumatic asplenia) and chronic conditions causing organ dysfunction such as diabetes, respiratory diseases, end-stage liver or kidney disease $[17,18]$. In order to attempt to establish the type and the level of response, immunoglobulin subsets and specific antibody levels can be measured, while cellular immunity can be assessed through concentrations and proportions of lymphocyte subsets and lymphocyte proliferation assays [19]. Clinically significant response to immunisation is usually defined as either a seroconversion or a rise in antibody titre to a predefined level that is accepted as protective with at least partial recovery of B celland $\mathrm{T}$ cell-mediated immunity.

For certain vaccines such as pneumococcal vaccines, however, specific cut-off values have not been established for patients with AI [20-23] or, in case of influenza vaccines, responses may vary yearly according to the vaccine composition [24, 25]. Although it is universally recognised that individuals with AI show reduced response to immunisation compared with their nonimmunocompromised counterparts, antibody titres following immunisation remain poorly investigated in this group, and data is usually derived from observational studies [22, 24, 26-41]. Furthermore, even in the presence of adequate titres, the antibody function may be impaired, or the response duration may be limited over time [42-45]. Assessment of antibody titres to measles, rubella, varicella zoster virus (VZV), tetanus and hepatitis B may guide clinicians in the assessment of need for vaccination, revaccination or administration of booster doses, although the timing for serological assessment may vary according to the underlying disease and type of AI [2-12].

A summary of the main studies investigating serological responses to the most commonly used inactivated vaccines in patients with $\mathrm{AI}$ is reported in supplementary table 1 .

High-risk populations are exposed to suboptimal protection from vaccination not only because of their reduced immune response to vaccinal antigens but also due to false contraindications to immunisation or the limited possibility to adequately recruit these populations during hospital admission or ambulatory visits. In this context, a key role in identifying patients who would benefit from vaccination is played by vaccine providers, including infectious diseases and public health specialists as well as primary care physicians. Other challenges are represented by a low protection given by immunisations, the need for multiple boosting doses, the increased adverse effects to live vaccines, and the difficulty to define the stage of immunodepression or to identify the ideal timing for administering a vaccine in patients with AI (Fig. 1).

Here we aim to summarise the evidence on vaccination principles and recommendations in adult patients with secondary immunodeficiencies, including asplenia, HIV infection, stem cell and solid organ transplant, haematological malignancies, inflammatory bowel disease and other chronic disorders. Vaccinations in primary immunodeficiencies have been reported elsewhere and are not discussed in this review [46].

\section{METHODS}

A Medline search was performed on July 30, 2020 using the following keywords: "vaccination" OR "immunization" OR "vaccine" AND "immunocompromised" OR "immune dysfunction" OR "immune depression" OR "impaired immunity" OR "altered immunocompetence". All types of articles published in English over the last 10 years and including patients older than 18 years of age were screened; references of selected studies were further revised to identify additional relevant publications. A summary of the main guidelines that are currently available 
Table 1 Main international or national guidelines, recommendations or reviews of vaccinations among subjects with altered immunocompetence $(\mathrm{AI})$ published in the past 10 years

\begin{tabular}{|c|c|c|}
\hline Reference & Country/society & AI population \\
\hline Danziger-Isakov et al. [3] & USA/American Society of Transplantation (AST) & $\begin{array}{l}\text { Solid organ transplant } \\
\text { recipients }\end{array}$ \\
\hline Cordonnier et al. [4] & $\begin{array}{l}\text { Multinational/from the European Conference on Infections in } \\
\text { Leukaemia (ECIL) }\end{array}$ & HSCT \\
\hline Mikulska et al. [5] & $\begin{array}{l}\text { Multinational/from the European Conference on Infections in } \\
\text { Leukaemia (ECIL) }\end{array}$ & $\begin{array}{l}\text { Patients with haematological } \\
\text { disorders }\end{array}$ \\
\hline Martire et al. [6] & Italy/Italian Primary Immunodeficiencies Network (IPINET) & Multiple \\
\hline Lopez et al. [7] & France & Multiple \\
\hline Frésard et al. [8] & France & HIV-infected \\
\hline Rahier et al. [9] & Europe/European Crohn's and Colitis Organisation (ECCO) & Inflammatory bowel disease \\
\hline Rubin et al. [2] & USA/Infectious Diseases Society of America (IDSA) & Multiple \\
\hline Wasan et al. $[10]$ & USA & Inflammatory bowel disease \\
\hline Davies et al. [12] & UK/British Committee for Standards in Haematology (BCSH) & Patients with asplenia \\
\hline Hilgendorf et al. [11] & Germany & HSCT \\
\hline $\begin{array}{l}\text { Australian Department of } \\
\text { Health }\end{array}$ & Australia/Updated 2020 & Multiple \\
\hline Government of Canada & Canada/Updated 2019 & Multiple \\
\hline CDC & $\begin{array}{l}\text { USA/Advisory Committee on Immunization Practices (ACIP) } \\
\text { Updated } 2020\end{array}$ & Multiple \\
\hline
\end{tabular}

$H I V$ human immunodeficiency virus, $H S C T$ haematopoietic stem cell transplant, CDC Centers for Infectious Disease Control and Prevention

[2-12, 47-49] for immunisation among patients with AI is reported in Table 1 . Various terms are used in the literature to define the status of impaired immune response. To avoid confusion, we used the label altered immunocompetence (AI) throughout the manuscript.

This article is based on previously conducted studies and does not contain any studies with human participants or animals performed by any of the authors.

\section{PRINCIPAL VACCINES USED IN PATIENTS WITH AI}

Although significant variations in recommended vaccines and schedules exist among countries, routine vaccines in healthy subjects include both inactivated and live attenuated products, while in some groups of patients with AI live attenuated vaccines may not be indicated $[2-5,29,47-49]$. Inactivated vaccines that are usually recommended for healthy subjects include those against diphtheria, tetanus, pertussis, polio, hepatitis B (HBV) and Haemophilus influenzae type $\mathrm{b}$, as well as boosters (i.e. tetravalent diphtheria-tetanus-pertussis-inactivated polio vaccine, trivalent diphtheria-tetanus-pertussis vaccine and bivalent diphtheriatetanus vaccine), pneumococcal conjugate and meningococcal conjugate vaccine and papillomavirus (HPV) vaccines [2-5, 29, 47-49]. Vaccination against pneumococcus, 


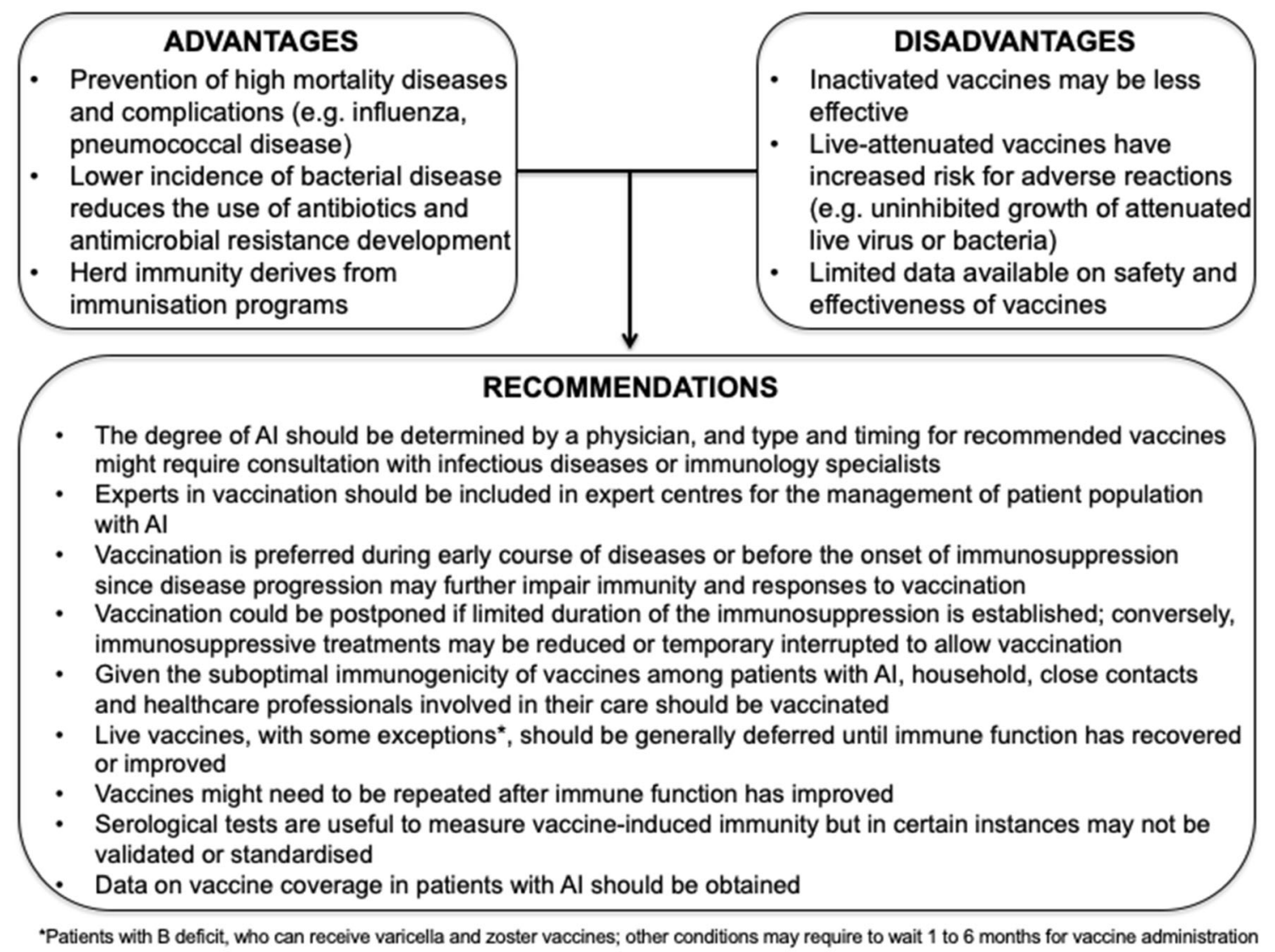

Fig. 1 Challenges in the immunisation of patients with altered immunocompetence (AI)

meningococcus, H. influenzae type $\mathrm{b}$ and influenzavirus is briefly described below.

\section{Pneumococcal Vaccine}

Both PCV13 (PCV, conjugate pneumococcal vaccine) and PPV23 (PPV, polysaccharide pneumococcal vaccine) are used in people who have increased risk for invasive pneumococcal disease (e.g. congenital immunodeficiency disorders, anatomic or functional asplenia, HIV infection, cochlear implant, cerebrospinal fluid leak, chronic renal failure, iatrogenic immunosuppression) [50]. Although PPV is recommended owing to its extended serotype coverage, the antibody response after vaccination is transitory since polysaccharides are $\mathrm{T}$ cell-independent antigens and induce IgM-dominated antibody responses without adequate immunological memory, resulting in a declined protection after $2-4$ years $[20,51,52]$.
Conversely, conjugate vaccines are highly immunogenic, provide higher antibody titres and induce immunological memory through covalent linkage of polysaccharide to a carrier protein (conjugation) that increases protection by inducing a $\mathrm{T}$ cell-dependent immune response [53]. Pneumococcal vaccination is indicated in all patients with AI, and particularly among those with asplenia and renal disease $[12,20,22,42]$. Both PVC and PPV are recommended in adults with established intervals between administration [2-12]. Specifically, sequential administration of PCV followed by PPV after at least 8 weeks is recommended and followed by a second dose of PPV after 5 years, although not all guidelines report the administration of boosters [20, 47]. If the patient already received PPV, PCV should be administered at least 1 year after the most recent PPV dose [20, 47, 54]. 


\section{Meningococcal Vaccines}

Both MenACWY (meningococcal conjugate vaccine) and MenB (serogroup B meningococcal vaccine) vaccines are universally recommended for people with functional or anatomic asplenia or persistent complement component deficiency, including those receiving treatment with eculizumab $[13,55]$ and may be suggested among other AI such as haematological diseases $[49,55,56]$. Vaccine schedule varies according to the patient's age and type of AI [47-49, 57, 58].

\section{Haemophilus Influenzae Type B (Hib) Vaccine}

Recipients of haematopoietic stem cell transplants (HSCT) should be revaccinated with three doses of Hib vaccine, starting 6-12 months after successful transplant, regardless of vaccination history or age [2]. As a result of the low incidence of $H$. influenzae among HIV-infected adults and the fact that this infection in advanced HIV disease is mainly related to non-typable strains, Hib vaccination is not routinely recommended in HIV-infected adults, although some guidelines still recommend it, especially in case of associated risk factors such as asplenia [6, 8, 48]. Nonimmunised asplenic adults should receive a dose of Hib vaccine [7]. Hib vaccine is also recommended in patients with complement component deficiency, IgG deficit and those undergoing chemotherapy [47].

\section{Influenzavirus Vaccines}

Despite studies showing lower immune responses in patients with impaired immunity compared to healthy control subjects, the risks for influenza-like illness are reduced by vaccination; therefore, seasonal influenza vaccine is recommended in all immunocompromised patients aged 6 months and older [2-12, 47-49, 59]. Since AI include a heterogeneous range of conditions, risk levels for severe flu infection vary across different populations [59]. Furthermore, limited data are available regarding the use of different types of influenza vaccines in the setting of AI [59]. In general, people with AI should receive age-appropriate trivalent or quadrivalent inactivated influenza vaccines (IIV) or recombinant influenza vaccine [60]. ACIP recommends that live attenuated influenza vaccines are not used for these groups because of the uncertain but potential risk for disease attributable to the vaccine virus [47]. Strategies to improve influenza vaccine immunogenicity have been attempted including intradermal, adjuvanted and high-dose vaccines $[59,61]$. Although repeated influenzavirus vaccination in $\mathrm{AI}$ is not universally recommended [4, 5], administration of two vaccine doses in the same influenza season has shown to increase antibody response $[22,49,62]$.

\section{IMMUNISATION IN PATIENTS WITH ALTERED IMMUNITY}

\section{Immunisation in Asplenia}

The asplenic population includes patients with surgical, functional and congenital asplenia. While surgical asplenia may occur in otherwise healthy patients (e.g. after trauma) or in patients with an underlying haematologic or immunologic indication for splenectomy, functional asplenia is associated with various diseases including haemoglobinopathies, chronic myeloproliferative disorders, and lymphoproliferative diseases. The spleen is the most efficient organ for clearing IgG-coated bacteria and is critical for the clearance of virulent encapsulated bacteria that are not opsonized by antibodies or complement [63, 64]. Asplenic persons also have humoral immune dysfunction, with a reduction in serum IgM antibodies to polysaccharides as well as a reduction in memory B cells producing IgM antibodies. Furthermore, the development of IgM antibodies to polysaccharide antigens is impaired, with a delayed and reduced response to vaccination [63]. The risk of fatal post-splenectomy sepsis is approximately $0.10-0.13$ cases per 100 patientyears in adults [65]. In these patients, sepsis is mainly caused by encapsulated organisms, 
Table 2 Suggested schedule for immunisation in adults with asplenia/splenic hypofunction and splenectomy

\begin{tabular}{|c|c|c|c|c|}
\hline Vaccination history & Month 0 & $\begin{array}{l}\text { Month } \\
1\end{array}$ & Month 2 & After month 2 \\
\hline Unvaccinated & $\begin{array}{l}\text { Hib/MenACWY } \\
\text { First dose PCV } \\
\text { Seasonal influenza }^{a}\end{array}$ & MenB & MenACWY & $\begin{array}{l}\text { PPV at least } \\
2 \text { months after } \\
\text { PCV } \\
\text { Seasonal influenza }{ }^{a}\end{array}$ \\
\hline PPV & $\begin{array}{l}\text { Hib/MenACWY/ } \\
\text { MenB } \\
\text { PCV (at least } 1 \text { year } \\
\text { after PPV) } \\
\text { Seasonal influenza }\end{array}$ & MenB & MenACWY & $\begin{array}{l}\text { MenACWY every } \\
5 \text { years } \\
\text { PPV } 5 \text { years after } \\
\text { PPV } \\
\text { Seasonal influenza }\end{array}$ \\
\hline MenACWY/MenB vaccination ( $>5$ years) & $\begin{array}{l}\text { Hib/MenACWY } \\
\text { PCV13 (at least } \\
1 \text { year after PPV) } \\
\text { Seasonal influenza }\end{array}$ & MenB & MenACWY & $\begin{array}{l}\text { MenACWY every } \\
5 \text { years } \\
\text { PPV } 5 \text { years after } \\
\text { PPV } \\
\text { Seasonal influenza }\end{array}$ \\
\hline $\begin{array}{l}\text { Completed MenACWY/MenC; Hib and PCV } \\
\text { vaccination more than } 5 \text { years before }\end{array}$ & $\begin{array}{l}\text { Hib/MenACWY } \\
\text { PCV } \\
\text { Seasonal influenza }\end{array}$ & MenB & PPV & $\begin{array}{l}\text { MenACWY every } \\
5 \text { years } \\
\text { PPV } 5 \text { years after } \\
\text { PPV } \\
\text { Seasonal } \\
\text { influenza } \infty\end{array}$ \\
\hline
\end{tabular}

Timing: Functional asplenia-as soon as possible. Surgical asplenia (elective)—complete the vaccination schedule 4-6 weeks before surgery; if not possible, complete at least 2 weeks before surgery. Surgical asplenia (emergency) - start the vaccination schedule at least 2 weeks after the operation or as soon as the clinical conditions permit

$P C V$ pneumococcal conjugate vaccine, $P P V$ pneumococcal polysaccharide vaccine, $H i b$ H. influenzae type b vaccine, Men ACWY N. menigitidis serotypes $\mathrm{A}, \mathrm{C}, \mathrm{W}, \mathrm{Y}$ vaccine, $\operatorname{Men} C$ N. meningitidis $\mathrm{C}$ vaccine

a Otherwise healthy asplenic patients 2-49 years of age may be vaccinated with live attenuated influenza vaccine, except patients with sickle cell disease, who should receive inactivated influenza vaccine

particularly S. pneumoniae, H. influenzae type b and Neisseria meningitidis, and vaccination against these pathogens is a mainstay of prevention of fatal sepsis. The risk of infection is greater in the first 2 or 3 years after the onset of asplenia or after splenectomy: $30 \%$ of infections occur during the first year and 50\% during the first 2 years [66]. However, the risk remains high for life. Antibody response to PCV was demonstrated from in vivo and in vitro studies, and PCV has been administered safely both before and after polysaccharide vaccines post splenectomy [42, 67]. MenACWY confers high and long-lasting immunity in this group $[2,68]$. The risk of invasive infection with Hib among adults remains low. Therefore, in low-risk populations it is reasonable to limit Hib vaccination in adults who were not previously vaccinated [2]. Table 2 summarises the recommendation for vaccinations in adult patients with asplenia. 


\section{Recipients of Haematopoietic Stem Cell Transplantation (HSCT)}

HSCT patients are at high risk of developing infections caused from capsulated bacteria [69]. Greater infection risk has been reported in allogeneic compared to autologous HSCT recipients because of a more pronounced and prolonged immunodepression caused not only by the underlying disease but also the potential occurrence of graft versus host disease (GVHD) and its related immunomodulatory prophylaxis and treatment $[2,70,71]$. Both chemotherapy and radiotherapy administered prior to transplantation represent the main reasons for the loss of previously acquired immunity in this group [11, 70-72]. Therefore, all HSCT candidates should receive immunisations since patients' pre-transplant immune status can increase the response following transplantation [4, 11, 70-72]. Non-immunosuppressed patients should complete the vaccination schedule according to their age and immune history (e.g. previous vaccinations or exposures), while the immunosuppressed ones should follow the immunisation recommendations according to the category of risk determined by their affecting disease [4]. Table 3 reports the recommended vaccination schedules in HSCT patients according to the main available guidelines. Inactivated vaccines (including booster doses) and live vaccines should be administered, respectively, at least 2 and 4 weeks before conditioning treatment [27-29, 32]. Current immunisation programs tend to consider HSCT patients as "never immunised", although it is recognised that immune memory to pre-transplant vaccinations may vary according to the type of transplant and that partial immune reconstitution can occur after HSCT [4]. Between 6 and 12 months after transplantation, $\mathrm{T}$ cells able to respond to new antigens are generated, especially among autologous HSCT recipients $[4,11,70-72]$. However, following allogeneic transplantation, immunity is considered decayed regardless of pre-transplant vaccination status and patients need to be revaccinated. Antibody titres to measles, rubella, VZV, tetanus and HBV should be evaluated in any case 3-6 months after transplantation [72]. While post-transplant immune reconstitution varies from subject to subject and is delayed in case of GVHD, most transplanted patients have an effective antibody response to vaccines 6 months after transplantation that will continue to improve $[4,70]$. In certain groups, such as patients treated with rituximab, a delayed reconstitution of the $B$ cell response is expected, and vaccinations should not be administered for at least 6-12 months after the completion of treatment [70]. In conclusion, timing for post-transplant vaccination in HSCT patients should be assessed individually $[34,35]$. Antibody titres for which a correlation of protection is available should be checked every 5 years in revaccinated patients in order to guide administration of booster doses $[4,70]$. For other vaccines, such as pneumococcal, meningococcal and flu vaccines, although IgG titres after PCV appeared an appropriate surrogate for the immune response in HSCT recipients, recommendations regarding protective antibody cannot be given because of the lack of standardized testing and established protective thresholds in adults [21]. Reduced but detectable antibody response to PCV has been demonstrated in HSCT up to 10 years after vaccination, while response to MenACWY significantly decreased starting from 6 months after immunisation [73, 74]. It is strongly recommended to vaccinate the household contacts of HSCT patients for measles, pertussis, VZV, mumps and influenza [70, 71].

\section{Haematological Malignancies}

In patients with haematological malignancies (HM) the immune system deficiency depends on the type of underlying disease (e.g. multiple myeloma and chronic lymphocytic leukaemia determine a deficit of humoral immunity, while lymphomas mainly affect cell-mediated immunity) and it is influenced by age [75]. Type, extent and duration of the immunodeficiency are also influenced by the type of chemotherapy undertaken and may predispose to different type of infections; for instance, rituximab and other anti-CD20 monoclonal antibodies cause a prolonged B lymphocyte deficiency that can 
Table 3 Recommended vaccination for adults after HSCT

\begin{tabular}{|c|c|c|c|}
\hline $\begin{array}{l}\text { Type of } \\
\text { vaccine }\end{array}$ & Doses & Timing & Comments \\
\hline \multicolumn{4}{|c|}{ Allogeneic HSCT } \\
\hline PCV & $\begin{array}{l}3 \text { (second and third at } \\
\text { least } 4 \text { weeks after } \\
\text { the previous one) }\end{array}$ & First 3-6 months after HSCT & $\begin{array}{l}\text { Fourth dose } 6 \text { months after the third one in } \\
\text { case of chronic GVHD }\end{array}$ \\
\hline PPV & 1 & $\begin{array}{l}12 \text { months after HSCT and at } \\
\text { least } 8 \text { weeks after last PCV }\end{array}$ & $\begin{array}{l}\text { Only in absence of GVHD } \\
\text { Booster dose } 5 \text { years after PPV }\end{array}$ \\
\hline MenACWY & $\begin{array}{l}2 \text { (at least } 8 \text { weeks } \\
\text { apart) }\end{array}$ & 6-12 months after HSCT & $\begin{array}{l}\text { Recommended in case of } \\
\text { anatomical/functional asplenia, } \\
\text { complement deficiency }\end{array}$ \\
\hline MenB & $\begin{array}{l}2 \text { (at least } 4 \text { weeks } \\
\text { apart) }\end{array}$ & 6-12 months after HSCT & $\begin{array}{l}\text { Recommended in case of } \\
\text { anatomical/functional asplenia, } \\
\text { complement deficiency }\end{array}$ \\
\hline $\mathrm{Hib}$ & $\begin{array}{l}3 \text { (second and third at } \\
\text { least } 4 \text { weeks apart) }\end{array}$ & $\begin{array}{l}\text { 3-6 months after HSCT } \\
\text { In case of simultaneous } \\
\text { administration of dTpa-IPV, } \\
\text { first dose 6-12 months after } \\
\text { HSCT }\end{array}$ & - \\
\hline $\begin{array}{l}\text { Inactivated } \\
\text { influenza } \\
\text { vaccine }\end{array}$ & Seasonal vaccination & 6-12 months after HSCT & $\begin{array}{l}\text { During outbreaks start } 3 \text { months after HSCT } \\
\text { ( } \pm \text { dose after } 4 \text { weeks })\end{array}$ \\
\hline dTpa & 3 (0, 1,6 months) & 6-12 months after HSCT & $\begin{array}{l}\text { If no antibody titre } 36 \text { months after HSCT, } \\
\text { booster dose }\end{array}$ \\
\hline IPV & 3 (0, 1,6 months) & 6-12 months after HSCT & - \\
\hline $\mathrm{HBV}$ & 3 (0, 1, 6 months) & 6-12 months after HSCT & $\begin{array}{l}\text { Unvaccinated or anti-HBsAb }<10 \mathrm{IU} / \mathrm{L} \text { or } \\
\text { previous infection with } \mathrm{HBs} \mathrm{Ab}<10 \mathrm{IU} / \mathrm{L} \\
\text { Revaccinate if at risk/not protective anti- } \\
\mathrm{HbsAb} \text { after } 1-2 \text { month }^{\mathrm{c}} \text { of a } 3 \text {-dose } \\
\text { schedule }\end{array}$ \\
\hline $\mathrm{VZV}^{\mathrm{a}}$ & $\begin{array}{l}2 \text { (at least } 4 \text { weeks } \\
\text { apart) }\end{array}$ & 24 months after HSCT & $\begin{array}{l}\text { Seronegative without GVHD; at least } \\
6 \text { months after CT discontinuation; at least } \\
8 \text { months after Ig discontinuation }\end{array}$ \\
\hline $\mathrm{HPV}$ & 3 doses & 6-12 months after HSCT & If at risk \\
\hline Yellow fever & 1 dose & 5 years after HSCT & No if chronic GVHD or CT \\
\hline
\end{tabular}


Table 3 continued

\begin{tabular}{|c|c|c|c|}
\hline $\begin{array}{l}\text { Type of } \\
\text { vaccine }\end{array}$ & Doses & Timing & Comments \\
\hline \multicolumn{4}{|c|}{ Autologous HSCT } \\
\hline dTpa & $\begin{array}{l}3 \text { with booster based } \\
\text { on antibody titre }\end{array}$ & 6-12 months after HSCT & $\begin{array}{l}\text { Tetanus: antibody titre evaluation } \\
\text { Pertussis: if never vaccinated, } 1 \text { dose of DTaP } \\
\text { and } 2 \text { doses of } \mathrm{dT}\end{array}$ \\
\hline $\begin{array}{l}\text { Inactivated } \\
\text { influenza } \\
\text { vaccine }\end{array}$ & Seasonal vaccination & 4-6 months after HSCT & - \\
\hline $\mathrm{HBV}$ & 3 (0, 1, 6 months) & 6-12 months after HSCT & $\begin{array}{l}\text { Unvaccinated or anti-HBsAb }<10 \mathrm{IU} / \mathrm{L} \text { or } \\
\text { previous infection with anti- } \\
\mathrm{HBs} \mathrm{Ab}<10 \mathrm{IU} / \mathrm{L} \text {; revaccinate if at risk/ } \\
\text { not protective anti-HbsAb after } \\
1-2 \text { months }^{\mathrm{b}} \text { of a } 3 \text {-dose schedule }\end{array}$ \\
\hline PCV & $\begin{array}{l}3 \text { (second and third at } \\
\text { least } 4 \text { weeks apart) }\end{array}$ & 3-6 months after HSCT & - \\
\hline PPV & 1 & $\begin{array}{l}12 \text { months after HSCT and at } \\
\text { least } 8 \text { weeks after PCV }\end{array}$ & Booster dose 5 years after PPV \\
\hline $\mathrm{MMR}^{\mathrm{b}}$ & $\begin{array}{l}2 \text { doses (at least } \\
4 \text { weeks apart) }\end{array}$ & 24 months after HSCT & $\begin{array}{l}\text { No protective titre for measles and/or rubella } \\
24 \text { months after HSCT and at least } \\
6 \text { months after CT and at least } 8 \text { weeks } \\
\text { after Ig }\end{array}$ \\
\hline$V_{Z V} V^{a}$ & $\begin{array}{l}2 \text { doses (at least } \\
4 \text { weeks apart) }\end{array}$ & 24 months after HSCT & $\begin{array}{l}\text { Seronegative and at least } 6 \text { months after CT } \\
\text { and at least } 8 \text { months after Ig } \\
\text { Evaluate antibody titre between first and } \\
\text { second dose }\end{array}$ \\
\hline
\end{tabular}

HZ (live), BCG, typhoid (oral) are contraindicated

$H S C T$ haematopoietic stem cell transplantation, GVHD graft versus host disease, $C T$ chemotherapy, $I g$ immunoglobulin, $P C V$ pneumococcal conjugate vaccine, $P P V$ polysaccharide pneumococcal vaccine, $H i b, H$. influenzae type b conjugate vaccine, MenACWY, conjugate vaccine against $N$. meningitidis A, C, W, Y, MenB conjugate vaccine against $N$. meningitidis B, DTaP diphtheria tetanus acellular pertussis for adults, $d T$ diphtheria tetanus vaccine, $d T p a$ diphtheria tetanus pertussis vaccine, $I P V$ inactivated anti-polio vaccine, $H B V$ hepatitis B vaccine, $V Z V$ varicella vaccine, $H P V$ papillomavirus vaccination, $M M R$ mumps, measles, rubella vaccination, $H Z$ live herpes zoster vaccine, $B C G$ tuberculosis vaccination, $H B s A b$ hepatitis $\mathrm{B}$ surface antibody

a Live vaccines are contraindicated in subjects with chronic GVHD, receiving CT and with disease recurrence

b If on intravenous Ig, evaluate specific antibody titre 3 months after its discontinuation

last for up 24 months after treatment [76]. Patients with HM are usually ideal candidates for vaccination since they are susceptible to infections caused by encapsulated bacteria that are associated with high morbidity and mortality but could be prevented by immunisation [5]. Nevertheless, evidence of immunisation effectiveness and serological responses is often 
Table 4 Recommended vaccination for adults with haematological malignancies

\begin{tabular}{|c|c|c|c|}
\hline Type of vaccine (dose) & $\begin{array}{l}\text { Underlying disease/ } \\
\text { therapy }\end{array}$ & $\begin{array}{l}\text { Timing } \\
\text { according } \\
\text { CT }\end{array}$ & Indication for vaccination \\
\hline PCV (one dose) & Acute leukaemia & After CT & Only if remission \\
\hline \multirow[t]{4}{*}{$\begin{array}{l}\text { PPV (one dose at least } 8 \text { weeks after } \\
\text { PCV) }\end{array}$} & $\begin{array}{l}\text { Indolent lymphomas, } \\
\text { lymphoproliferative } \\
\text { syndromes, multiple } \\
\text { myeloma }\end{array}$ & $\begin{array}{l}\text { Before or } \\
\text { after CT }\end{array}$ & $\begin{array}{l}\text { Patients who need CT } \\
\text { immediately vaccinate } 3 \text { months } \\
\text { after treatment; otherwise, } \\
\text { before CT }\end{array}$ \\
\hline & $\begin{array}{l}\text { Myeloproliferative } \\
\text { disorders, chronic } \\
\text { myelodysplastic syndrome }\end{array}$ & Before CT & At diagnosis \\
\hline & Anti-CD20 & $\begin{array}{l}>6 \text { months } \\
\text { after CT }\end{array}$ & At least 6 months after treatment \\
\hline & Checkpoint Inhibitors & Before CT & As soon as possible \\
\hline \multirow[t]{3}{*}{ Hib (one dose) } & Acute leukaemia & After CT & Only if remission \\
\hline & $\begin{array}{l}\text { Indolent lymphomas, } \\
\text { lymphoproliferative } \\
\text { syndromes, multiple } \\
\text { myeloma }\end{array}$ & $\begin{array}{l}\text { Before or } \\
\text { after CT }\end{array}$ & $\begin{array}{l}\text { Patients who need CT } \\
\text { immediately vaccinate } 3 \text { months } \\
\text { after treatment; otherwise, } \\
\text { before CT }\end{array}$ \\
\hline & $\begin{array}{l}\text { Myeloproliferative } \\
\text { disorders, chronic } \\
\text { myelodysplastic } \\
\text { syndrome }\end{array}$ & Before CT & Vaccinate at diagnosis \\
\hline \multirow{3}{*}{$\begin{array}{l}\text { MenACWY ( } 2 \text { doses at least } 8 \text { weeks } \\
\text { apart; booster dose every } 5 \text { years); } \\
\text { MenB (according to schedule) }\end{array}$} & Acute leukaemia & After CT & Vaccinate only if remission \\
\hline & $\begin{array}{l}\text { Indolent lymphomas, } \\
\text { lymphoproliferative } \\
\text { syndromes, multiple } \\
\text { myeloma }\end{array}$ & $\begin{array}{l}\text { Before or } \\
\text { after CT }\end{array}$ & $\begin{array}{l}\text { Patients who need CT } \\
\text { immediately vaccinate } 3 \text { months } \\
\text { after treatment; otherwise, } \\
\text { before CT }\end{array}$ \\
\hline & $\begin{array}{l}\text { Myeloproliferative } \\
\text { disorders, chronic } \\
\text { myelodysplastic } \\
\text { syndrome }\end{array}$ & Before CT & At diagnosis \\
\hline
\end{tabular}


Table 4 continued

\begin{tabular}{|c|c|c|c|}
\hline Type of vaccine (dose) & $\begin{array}{l}\text { Underlying disease/ } \\
\text { therapy }\end{array}$ & $\begin{array}{l}\text { Timing } \\
\text { according } \\
\text { CT }\end{array}$ & Indication for vaccination \\
\hline \multirow[t]{6}{*}{ Inactivated influenza vaccine (seasonal) } & Acute leukaemia & After CT & \multirow{4}{*}{$\begin{array}{l}\text { Before CT or during CT (after } \\
\text { the cycle of just before next } \\
\text { one) }\end{array}$} \\
\hline & $\begin{array}{l}\text { Indolent lymphomas, } \\
\text { lymphoproliferative } \\
\text { syndromes, multiple } \\
\text { myeloma }\end{array}$ & $\begin{array}{l}\text { Before or } \\
\text { after CT }\end{array}$ & \\
\hline & $\begin{array}{l}\text { Myeloproliferative } \\
\text { disorders, chronic }\end{array}$ & $\begin{array}{l}\text { Before or } \\
\text { after CT }\end{array}$ & \\
\hline & myelodysplastic syndrome & & \\
\hline & Anti-CD20 & $\begin{array}{l}>6 \text { months } \\
\text { after CT }\end{array}$ & At least 6 months after treatment \\
\hline & Checkpoint Inhibitors & Before CT & As soon as possible \\
\hline \multirow{3}{*}{$\begin{array}{l}\text { TDP (tetanus based on antibody titre); } \\
\text { dTpa (one dose) and dT (two doses); } \\
\text { dTpa booster dose every } 10 \text { years }\end{array}$} & Acute leukaemia & After CT & Only if remission \\
\hline & $\begin{array}{l}\text { Indolent lymphomas, } \\
\text { lymphoproliferative } \\
\text { syndromes, multiple } \\
\text { myeloma }\end{array}$ & $\begin{array}{l}\text { Before or } \\
\text { after CT }\end{array}$ & $\begin{array}{l}\text { Patients who need CT } \\
\text { immediately vaccinate } 3 \text { months } \\
\text { after treatment; otherwise, } \\
\text { before CT }\end{array}$ \\
\hline & $\begin{array}{l}\text { Myeloproliferative } \\
\text { disorders, chronic } \\
\text { myelodysplastic } \\
\text { syndrome }\end{array}$ & Before CT & At diagnosis \\
\hline
\end{tabular}

CT chemotherapy, PCV13 pneumococcal conjugate vaccine 13 valent, PPV23 polysaccharide pneumococcal vaccine 23 valent, $H i b H$. influenzae type b conjugate vaccine, Men $C A W Y$ conjugate vaccine against $N$. meningitidis $\mathrm{A}, \mathrm{C}, \mathrm{W}, \mathrm{Y}$, Men $B$ conjugate vaccine against $N$. meningitidis $\mathrm{B}, D T P$ diphtheria tetanus pertussis vaccine, $d T p a$ diphtheria tetanus acellular pertussis for adults, $d T$ diphtheria tetanus vaccine

limited, and data are extrapolated from studies conducted in the general population [5]. Live vaccines are contraindicated in subjects suffering from lymphomas, leukaemia and other malignant diseases of the bone marrow or lymphatic system, as well as in people undergoing immunosuppressive treatment [34]. These patients can receive inactivated vaccines, including those against encapsulated bacteria (e.g. S. pneumoniae, H. influenzae, N. meningitidis) and influenzavirus (Table 4) [77].

\section{Myeloid Diseases}

In patients with myeloid diseases such as acute myeloid leukaemia (AML), myelodysplastic syndrome and chronic myeloproliferative disorders, the efficacy of vaccination is influenced by the type of treatment received [5]. Tyrosine kinase inhibitors (TKI) are associated with increased risk of reactivation of hepatitis B and opportunistic, respiratory and skin infections. In patients receiving TKI and Janus kinase inhibitors (JAKi), a reduced efficacy of pneumococcal vaccination is reported [5]. Patients with myeloid diseases should receive 
inactivated vaccines such as those against pneumococcus, meningococcus and $H$. influenzae according to age and country guidelines; the need for a tetanus booster should be evaluated on the basis of their antibody titre $[5,77]$. A single dose of inactivated influenza vaccine should be administered yearly from the end of intensive chemotherapy, although the seroconversion rates remain low (e.g. not higher than 20\%) [70]. Patients suffering from myelodysplastic syndrome and chronic myeloproliferative disorders should be vaccinated shortly after diagnosis or, in any case, before starting chemotherapy. Patients with AML that usually cannot delay treatment should be vaccinated 3-6 months after the end of chemotherapy in case of disease remission [5].

\section{Chronic Lymphoproliferative Diseases}

In chronic lymphoproliferative diseases, the vaccination strategy is planned according to the type of therapy received, including rituximab, other anti-CD20 antibodies or drugs such as bortezomib, brentuximab, ibrutinib and lenalidomide [78]. Increased (between 50\% and $70 \%)$ IgG responses to vaccines such as PCV and inactivated influenza were detected among patients who were treatment-naïve or during disease plateau [24, 31-33]

Chronic diseases such as multiple myeloma (MM) or chronic lymphocytic leukaemia (CLL) that are not treated with HSCT have lower probability of restoring long-term immunity compared with aggressive diseases such as lymphomas that obtain a favourable response $[7,78] . \mathrm{MM}$ is associated with increased risk of invasive pneumococcal disease, influenza and herpes zoster virus reactivation [8]. For MM, serological responses have been reported among patients with no active diseases, although hypogammaglobulinemia or the production of ineffective antibodies may be possible, and opsonophagocytic activity assays did not correlate with antibody titres [23, 24, 79]. CLL is associated with an increased risk of Hib disease [78]. Although inactive vaccines in these patients are indicated and safe, their main limitation is a limited efficacy, especially in patients with severe hypogammabglobulinemia or treated with rituximab [79]. Indication for vaccinations against encapsulated bacteria, tetanus, HBV and influenzavirus should be individually reviewed at the end of induction therapy, after 3-6 months following chemotherapy and, in case of anti-CD20 antibody therapy, after at least 6 months after end of treatment [5]. In this group, better response with the use of PCV over PPV and greater efficacy administering a second dose (but only for adjuvanted influenza vaccines) have been reported $[5,31,80]$.

\section{Patients with Human Immunodeficiency Virus (HIV) Infection}

The availability of highly active antiretroviral treatment (HAART) since the mid-1990s improved both life expectancy and quality of life of HIV-positive subjects. In addition, thanks to the high tolerability of HIV medicaments and low risk of long-term side effects, HIV treatment guidelines now recommend starting the treatment soon after diagnosis, regardless of $\mathrm{CD} 4^{+}$ lymphocyte numbers $[81,82]$. HAART promotes the inhibition of HIV replication and achievement of viral undetectability, allowing the patients' immune system to recover [81, 82].The immunisation schedule of HIV-positive subjects is similar to that of non-HIV-positive ones, and various guidelines have been published addressing immunisations in this patient population $[2,48,49,56,83]$. Inactivated vaccines (e.g. tetanus, polio, diphtheria, HBV, pneumococcal and injectable influenza vaccinations) as well as HPV, because of the increased risk of HPV-related complications, are universally recommended [2, 6, 48, 49, 83], while Hib and meningococcal vaccinations are suggested by some learned societies [6, 48, 49] and hepatitis A (HAV) vaccination in high-risk groups such as travellers, people living in endemic areas, men who have sex with men, injecting drug users [83]. Some live vaccines are not recommended in patients with HIV [2, 6, 48, 49, 83], specifically BCG is contraindicated, while yellow fever vaccination, MMR and VZV may be considered among patients at high risk for acquiring these infections and $\mathrm{CD}^{+}$counts above $200 / \mathrm{mm}^{3}$. Serological responses to HBV 
Table 5 Recommended vaccines in patients with IBD

\begin{tabular}{|c|c|}
\hline Infectious agent & Vaccination schedule \\
\hline Tetanus, diphteria, pertussis & $\begin{array}{l}\text { All patients between } 11 \text { and } 64 \text { years of age should be vaccinated with a single dose } \\
\text { of dTpa. All patients should be vaccinated with Td every } 10 \text { years }\end{array}$ \\
\hline Hepatitis A & $\begin{array}{l}\text { HAV immune status should be checked at the patient's initial visit. If nonimmune } \\
\text { to HAV, patient should be vaccinated with a } 2 \text {-dose series ( } 0 \text { and } 6-12 \text { months) }\end{array}$ \\
\hline Hepatitis B & $\begin{array}{l}\text { HBV immune status should be checked at the patient's initial visit. If nonimmune } \\
\text { to } \mathrm{HBV} \text {, patient should be vaccinated with a } 3 \text {-dose series }(0,1-2 \text {, and } \\
4-6 \text { months) and recheck titres } 1 \text { month after the last dose. If no response, offer } \\
\text { booster with a double dose of HBV vaccine }\end{array}$ \\
\hline Human papilloma virus & $\begin{array}{l}\text { All male and female patients between } 11 \text { and } 26 \text { years of age should be vaccinated } \\
\text { with a } 3 \text {-dose series }(0,2 \text {, and } 6 \text { months) }\end{array}$ \\
\hline Influenzavirus & $\begin{array}{l}\text { All patients should receive annual immunisation with inactivated influenza } \\
\text { vaccine; live attenuated intranasal influenza vaccine is contraindicated in } \\
\text { immunosuppressed patients }\end{array}$ \\
\hline Neisseria meningitidis & $\begin{array}{l}\text { All adult patients should receive a 2-dose series of MenACWY and a 2-dose series } \\
\text { of MenB }\end{array}$ \\
\hline Streptococcus pneumoniae & $\begin{array}{l}\text { All patients with IBD should be vaccinated once with the PCV followed by the } \\
\text { PPV (first dose after } 8 \text { weeks if immunocompromised, or after } \geq 1 \text { year if } \\
\text { immunocompetent; second dose after } 5 \text { years). If previously vaccinated with the } \\
\text { PPV23, then PCV should be administered at least } 1 \text { year after the PPV }\end{array}$ \\
\hline Measles, mumps, rubella viruses & $\begin{array}{l}\text { Immune status should be checked at the patient's initial visit. If nonimmune, } \\
\text { patient should be vaccinated with a } 2 \text {-dose series ( }>4 \text { weeks apart) at least } \\
6 \text { weeks before starting immunosuppressive therapy, when feasible. } \\
\text { Recombinant inactivated vaccine may be considered }\end{array}$ \\
\hline Varicella virus & $\begin{array}{l}\text { Immune status should be checked at the patient's initial visit. If nonimmune, } \\
\text { patient should receive a } 2 \text {-dose series ( }>4 \text { weeks apart) of live attenuated } \\
\text { vaccine at least } 1 \text { month before starting high-dose immunosuppressive therapy, } \\
\text { when feasible }\end{array}$ \\
\hline Herpes zoster virus & $\begin{array}{l}\text { Patients older than } 50 \text { years of age should receive } 1 \text { dose of live attenuated vaccine } \\
\text { at least } 1 \text { month before starting high-dose immunosuppressive therapy, when } \\
\text { feasible. Recombinant inactivated vaccine may be considered }\end{array}$ \\
\hline
\end{tabular}

$H A V$ hepatitis A, $H B V$ hepatitis B, MenACWY meningococcal conjugate vaccine (quadrivalent), MenB serogroup B meningococcal vaccine, $P C V$ pneumococcal conjugate vaccine, $P P V$ pneumococcal polysaccharide vaccine, $T d$ adult/adolescent formulation of tetanus/diphtheria vaccine, Tdap adult/adolescent formulation of tetanus/diphtheria/(acellular)pertussis vaccine

(e.g. HBsAb less than $10 \mathrm{mIU} / \mathrm{mL} 1-2$ month after three high doses of $40 \mathrm{mg} \mathrm{HBV}$ vaccine) may be used to decide if booster doses of the vaccine are needed $[2,7]$. The choice of the best timing for vaccination and the type of vaccine to administer (e.g. inactivated or live vaccines), 
however, may depend on the $\mathrm{CD} 4^{+}$lymphocyte count (e.g. above or below 200 cells $/ \mathrm{mm}^{3}$ ) [2] For very low cell counts, the response to vaccination is expected to be poor and temporary and therefore booster doses may be necessary. Studies analysing specific antibody responses to HPV vaccine [84-86], HAV vaccine [87], PCV13 [37], inactivated influenza [88, 89] and HBV vaccine [90] showed lower responses for HIVpositive compared with HIV-negative patients, especially when low $\mathrm{CD}^{+}$counts or increased viral loads were detected. As a general rule, in order to maximise the efficacy and benefit of vaccination, avoiding ineffective doses, vaccines should be administered to HIV-positive subjects without significant immunosuppression (below $200 \mathrm{CD} 4$ cells $/ \mathrm{mm}^{3}$ ), such as early diagnosed patients with HIV or those stably receiving HAART with good immunovirological response [2, 91]. Although high viral load has been associated with reduced response to vaccination, this should not prevent indication to receive immunisation. In subjects with $\mathrm{CD}^{+}$ lymphocyte count lower than $200 / \mathrm{mm}^{3}$, live vaccines should be avoided, and inactivated vaccines postponed $[2,91]$.

\section{Vaccination in Patients with Inflammatory Bowel Disease}

Patients with inflammatory bowel disease (IBD) are not routinely considered to have altered immunocompetence per se, despite the evidence of impaired innate mucosal immunity [92]. Nevertheless, treatments with long-term immunosuppressive therapies make patients with IBD at increased risk of developing vaccine-preventable infections [92]. Low rates of vaccinations are often reported among patients with IBD, probably as a result of poor knowledge of the vaccinations recommended in this group $[92,93]$. One common concern is that vaccination may exacerbate IBD activity, despite several studies conducted in patients with rheumatologic disorders that failed to demonstrate an association between vaccination and disease progression, and no convincing evidence to support an association between an increase in IBD activity and vaccination is reported [94, 95]. In general, when feasible, adherence to age-appropriate vaccination schedules is strongly recommended before starting immunosuppressants [2, 9, 96-98].

Multiple studies have assessed the response to vaccination in patients with IBD $[99,100]$. In general, patients receiving monotherapy may have an adequate serologic response to vaccination, despite some studies reporting a diminished immune response in patients receiving anti-tumour necrosis factor (anti-TNF) monotherapy $[99,100]$ and a reduction of the response to orally administered vaccines in patients on vedolizumab, consistently with its gut-selective mechanism of action [101]. Conversely, a decreased serologic response to vaccination has been demonstrated in patients on combination therapy [99, 100]. It is unclear whether vaccination maintains an effective protection in case of an absent serological immune response. On the basis of these data, patients with IBD should ideally be vaccinated before starting the immunosuppressive therapy, as recommended by the current guidelines $[2,9,96,97]$. According to the American College of Gastroenterology, ACIP, IDSA, and the European Crohn's and Colitis Organisation $[2,9,96,97]$, all non-live vaccines can be administered to patients with IBD regardless of immunosuppression status [96, 98], including pneumococcal vaccination and vaccines against Hib, HAV, HBV, HPV, influenzavirus, tetanus and pertussis. HBV infection and reactivation are of great concern, especially in case of antiTNF therapy, as fulminant and fatal cases of HBV have been reported [102]. During flu season, patients with IBD should undergo annual vaccination because of a higher likelihood of influenza-related complications [2, 9, 95, 97, 103]. Table 5 provides a list of recommended vaccines in patients with IBD.

Research is currently underway regarding the safety of administering live vaccination to patients with IBD receiving high-dose immunosuppression. For this reason, live attenuated vaccines are generally recommended for patients on low-dose (prednisone equivalent $<20 \mathrm{mg} /$ day for $<14$ days, methotrexate $<0.4 \mathrm{mg} / \mathrm{kg} /$ week, azathioprine $<3.0 \mathrm{mg} /$ $\mathrm{kg} /$ day, or 6 -mercaptopurine $<1.5 \mathrm{mg} / \mathrm{kg} /$ day) 
but not high-dose immunosuppression [47]. The package insert for vedolizumab states that patients on this biologic agent may receive live vaccines if the benefits outweigh the risks, whereas patients treated with ustekinumab and tofacitinib should not receive live vaccines because of the lack of supporting evidence $[104,105]$. Patients with IBD are at a significantly increased risk of developing herpes zoster infections, which can occur at an early age as compared to the general population [106]. Treatment with corticosteroids, thiopurines and tofacitinib is associated with higher odds of developing herpes zoster infections [106-108] and a combination of anti-TNF and thiopurine further increases the risk of zoster [109]. According to the American College of Gastroenterology (ACG) guidelines, the administration of the live attenuated zoster vaccine is highly recommended even in patients with IBD on low-dose immunosuppression [95]. A recent study suggests that live zoster vaccine may be relatively safe in patients receiving anti-TNF agents [110]. Although the new inactivated formulation of zoster vaccine is available in various countries, its efficacy in patients with IBD has not been established yet.

\section{Solid Organ Transplantation (SOT) Recipients}

The recently published guidelines by the American Society of Transplantation (AST) recommend the review of the immunisation status early during pre-transplant evaluation [3]. Pneumococcal, influenza, HBV, HPV and meningococcal vaccines are the most frequently recommended inactivated vaccines among SOT candidates [3]. Both inactivated and live vaccines can be administered before transplantation, and appropriate vaccination should be updated during this time [3]. As patients who are candidates for SOT usually have end-stage organ disease, early vaccination assessment and administration should be performed by nephrologists, hepatologists, cardiologists, pneumologists and other healthcare providers who regularly assess SOT candidates. Following SOT, lower serological responses to immunisation have been reported compared to healthy subjects, although the data is usually limited to small studies and highly heterogeneous [29]. Furthermore, vaccination in the post-transplant setting presents some challenges and should take into account the timing from transplantation and the type of vaccine to be administered [3]. In particular, inactivated vaccines can be generally given starting at 3 months post transplant, with the exception of the influenza vaccine, which can be given as early as 1 month after transplantation, for example if transplantation occurs during the flu season [3]. The use of booster doses of influenza vaccine in SOT remains controversial [111]. A recent randomised controlled trial using two doses of trivalent IIV in SOT patients 1 month after transplantation was associated with higher short-term seroconversion [112]. Better seroprotection was also demonstrated in kidney transplant recipients receiving repeat doses of influenza vaccine, but similar results were not confirmed in liver transplant recipients [113]. While inactivated vaccines can be safely administered post transplant, live attenuated vaccines are generally contraindicated or should be considered on a case-by-case basis [3]. One exception is represented by nonimmunised children undergoing kidney or liver transplant and receiving very low doses of immunosuppressants and have no sign of organ rejection [2]. Regarding herpes zoster, both candidate and recipients of SOT may receive vaccination with the recently marketed subunit vaccines. Recent guidelines, however, are still cautious on the use of VZV subunit vaccination because of the paucity of data among immunosuppressed subjects [114].

\section{Neuromuscular Diseases}

Neuromuscular diseases include a wide spectrum of clinical conditions (e.g. dystrophies, myopathies, myasthenia gravis, polymyositis/dermatomyositis etc.) that are often burdened by high rates of vaccinepreventable infectious complications $[115,116]$. Respiratory complications (e.g. aspiration pneumonia, progressive respiratory 
Table 6 Recommended vaccines in patients with chronic diseases

\begin{tabular}{ll}
\hline Vaccine type (dose) & Chronic disease \\
\hline MenACWY (1 dose) & Non-malignant haematological disorders \\
Pneumococcal vaccine (PCV; PPV after at least & Non-malignant haematological disorders \\
12 months) & Chronic cardiac disease \\
& Chronic pulmonary disease \\
& Diabetes \\
& Patients who have or are candidates for cochlear implants \\
& Patients with chronic cerebrospinal fluid leaks due to trauma or surgical \\
& intervention \\
& Cystic fibrosis \\
& Patients who have or are candidates for cochlear implants \\
Hib (1 dose, if not previously vaccinated) & Haematological diseases (not cancer) \\
Influenza vaccine (seasonal) & Chronic cardiac and/or pulmonary disease \\
& Diabetes \\
& Cystic fibrosis \\
\hline
\end{tabular}

$\overline{M e n A C W Y}$ meningococcal conjugate vaccine (quadrivalent), $P C V$ pneumococcal conjugate vaccine, $P P V$ pneumococcal polysaccharide vaccine, $H i b H$. influenzae type b vaccine

disease), cardiovascular complications and AI associated with the use of immunosuppressive therapy (e.g. corticosteroids and anti-TNF therapy) can occur $[115,116]$. Similar to other patient populations, also in this group the need for vaccination is underestimated, and there is the fear that vaccination may negatively impact the course of the disease itself. Furthermore, healthcare personnel involved in neuromuscular disease centres of expertise do not usually include experts in vaccination. A study including 58 adult patients with myasthenia gravis and 208 healthy subjects suggested that the level of vaccine-induced immunity against diphtheria and tetanus was comparable between the groups [117]. Expert consensus recommends that patients with a neuromuscular disorder follow the same vaccination as the general population $[115,116]$. Two doses of live attenuated vaccines (e.g. measles, mumps, rubella and varicella vaccines) should be administered before the start of immunosuppressive therapies [115]. Seasonal influenza vaccination and pneumococcal vaccination are also recommended [116].

\section{Other Diseases}

Various chronic diseases (e.g. diabetes mellitus, cardiac and pulmonary diseases) in subjects who are otherwise considered immunocompetent may increase the risk of developing serious vaccine-preventable infections and their related complications $[118,119]$. It is therefore recommended that subjects with chronic diseases receive routine inactivated and live attenuated vaccines and update their vaccination status [118]. Vaccination should be planned in the early phases of the disease to allow higher immunogenicity $[120,121]$. If the disease progresses, patients' immunisation status should be reviewed.

Patients with heart diseases and diabetes mellitus, in particular, can develop flu-related complications and invasive pneumococcal 
disease, and have increased risk for disease progression or exacerbation requiring hospitalisation [122]. Patients with diabetes may have cardiovascular, renal and other disease-related end-stage organ disease and increased risk of acquiring HBV. In this group, pneumococcal vaccine, seasonal influenzavirus and $\mathrm{HBV}$ vaccinations are recommended [120, 123]. As a result of their reduced cellular mediated immunity, patients with diabetes mellitus are at risk for developing herpes zoster due to VZVspecific reduced immune response [124]. Some guidelines suggest administering anti-influenza, pneumococcal, HBV and herpes zoster vaccination in patients with diabetes mellitus $[120,123]$. Among patients with chronic respiratory diseases, flu vaccination is recommended, especially in patients suffering from chronic obstructive pulmonary disease. Pneumococcal vaccine is also recommended in this group and may reduce the use of antimicrobials associated with the treatment of bacterial diseases therefore impacting antimicrobial resistance [125]. Both inactivated and live vaccines can be administered in patients with cystic fibrosis. In this group, seasonal influenzavirus and pneumococcal vaccination are recommended [126]. Other suggested vaccinations include a two-dose varicella vaccine and, since patients with cystic fibrosis are at risk of associated liver disease, hepatitis vaccines [126].

In conclusion, patients who do not fulfil the definition of AI but present chronic diseases may still benefit from specific vaccinations, as summarized in Table 6.

\section{AREAS FOR FUTURE RESEARCH}

Although data from small trials or observational studies appear encouraging in favouring vaccination in $\mathrm{AI}$, some recommendations still remain poorly supported by evidence even in comprehensive and recent guidelines [2-12]. Furthermore, as highlighted in Table 1 in the supplementary material, the knowledge on serological and/or cellular responses in AI is still limited and few reports are available regarding optimal protection correlates in this population. Studies investigating the role of permanent protective humoral immune responses associated with long-lived plasma cells may inform new vaccine strategies aiming at reaching sufficient antigenic threshold of B cell stimulation, although this may be difficult among patients with impaired $\mathrm{B}$ responses [127].

An urgent need remains to plan prospective studies and adequately powered vaccination trials with relevant endpoints in well-defined AI subgroups. Specific groups of patients with AI may benefit from targeted assessment of their vaccine response and should be chosen according to their underlying disease (e.g. haploidentical or unrelated cord blood transplants (UCBT) recipients among patients with haematological disorders; recipients of different SOT), timing of immunosuppression (e.g. before or after anti-CD20 monoclonal antibody treatment) or type of therapy received (e.g. antiB monoclonal antibodies before and after HSCT or novel drugs such as blinatumomab and antiCD19/20/22 CAR T cells) [3-5].

There are still open questions regarding the use of recently introduced or marketed vaccines such as nonavalent HPV vaccine, inactivated VZV vaccine and SARS-CoV-2 vaccine in patients with AI. Although recommended in patients with AI at high risk for HPV infection according to national guidelines [128], the benefit of all types of HPV vaccinations in preventing HPV-related cancer still needs to be extensively evaluated in patients not included in the usual age-based recommendation. Recently, the efficacy and safety of the inactivated VZV vaccine for herpes zoster prevention was studied in a phase 3 randomised controlled trial encompassing 2637 patients with solid tumour or haematological malignancies [129]. Clinical efficacy was shown only in patients with solid tumours or autologous HSCT despite immunogenicity being detected in all groups by production of VZV-specific antibody responses $[129,130]$. Novel vaccine approaches (e.g. replication-deficient, adenovirus vector-based vaccines that contain the SARS-CoV-2 spike protein and mRNA-based vaccines that encode a SARS-CoV-2 spike protein) have been studied during the COVID-19 pandemic in 2020 [131]. Two vaccines, BNT162b2 Pfizer-BioNTech and 
mRNA-1273 Moderna, were given Emergency Use Authorization (EUA) on the basis of phase $1 / 2$ studies in the setting of a public health emergency [131-133]. Currently, no SARS-CoV-2 vaccine trial is enrolling patients receiving immunosuppressive therapy and no specific recommendations for individuals with AI have currently been made by ACIP [47]. The risks and benefits for immunocompromised patients receiving a SARS-CoV-2 vaccine should be therefore evaluated on a case-by-case basis, considering factors such as the incidence of infection in the community, the approved vaccine formulation available, the level of immunosuppression the patient has received and the underlying disease.

In conclusion, studies on optimal implementation of immunisation in individuals with AI should be pursued in future research, always taking into consideration country recommendations, age and timing of immunosuppression.

\section{CONCLUSIONS}

Vaccination of patients with AI is a priority because of the increased mortality associated with vaccine-preventable diseases. Suboptimal vaccine efficacy and safety concerns remain the most important challenges associated with vaccine administration in this patient population. While vaccination against $S$. pneumoniae and influenza is generally recommended in all patients with $\mathrm{AI}$, other vaccines and vaccine schedules should be personalised and administered according to the underlying disease. Correct timing for vaccine administration is also paramount, and may depend on many factors, such as concomitant immunosuppressive treatments or disease-related complications. Generally speaking, vaccination during the early course of diseases or before the onset of immunosuppression should be encouraged, since disease progression may further impair immunity and responses to vaccination. As a result of the multiple challenges associated with vaccination in patients with altered immunity, experts in vaccination should be included in all centres that manage these patients, and studies to investigate vaccine coverage in patients with AI should be encouraged.

\section{ACKNOWLEDGEMENTS}

Authorship. All named authors meet the International Committee of Medical Journal Editors (ICMJE) criteria for authorship for this article, take responsibility for the integrity of the work as a whole, and have given their approval for this version to be published.

Disclosures. Elda Righi, Tolinda Gallo , Anna Maria Azzini, Fulvia Mazzaferri, Maddalen Cordioli, Mara Merighi and Evelina Tacconelli have nothing to disclose.

Compliance with Ethics Guidelines. This article is based on previously conducted studies and does not contain any studies with human participants or animals performed by any of the authors.

Funding. No funding or sponsorship was received for this study or publication of this article.

Data Availability. Data sharing is not applicable to this article as no datasets were generated or analysed during the current study.

Open Access. This article is licensed under a Creative Commons Attribution-NonCommercial 4.0 International License, which permits any non-commercial use, sharing, adaptation, distribution and reproduction in any medium or format, as long as you give appropriate credit to the original author(s) and the source, provide a link to the Creative Commons licence, and indicate if changes were made. The images or other third party material in this article are included in the article's Creative Commons licence, unless indicated otherwise in a credit line to the material. If material is not included in the article's Creative Commons licence and your intended use is not permitted by statutory regulation or exceeds the permitted use, you will need to obtain permission directly from the 
copyright holder. To view a copy of this licence, visit http://creativecommons.org/licenses/by$\mathrm{nc} / 4.0 /$.

\section{REFERENCES}

1. Ljungman P. Vaccination of immunocompromised patients. Clin Microbiol Infect. 2012;18:93-9.

2. Rubin LG, Levin MJ, Ljungman P, et al. 2013 IDSA clinical practice guideline for vaccination of the immunocompromised host. Clin Infect Dis. 2014;58:e44-100.

3. Danziger-Isakov L, Kumar D. Vaccination of solid organ transplant candidates and recipients: Guidelines from the American Society of Transplantation Infectious Diseases Community of Practice. Clin Transplant. 2019;33(9):e13563.

4. Cordonnier C, Mikulska M, Einarsdottir S, Cesaro S, Ljungman P. 2017 ECIL 7 vaccine guidelines. Lancet Infect Dis. 2019;19:694-5.

5. Mikulska M, Cesaro S, de Lavallade H, et al. Vaccination of patients with haematological malignancies who did not have transplantations: guidelines from the 2017 European Conference on Infections in Leukaemia (ECIL 7). Lancet Infect Dis. 2019;19:188-199.

6. Martire B, Azzari C, Badolato R, et al. Vaccination in immunocompromised host: recommendations of Italian Primary Immunodeficiency Network Centers (IPINET). Vaccine. 2018;36:3541-54.

7. Lopez A, Mariette X, Bachelez H, et al. Vaccination recommendations for the adult immunosuppressed patient: a systematic review and comprehensive field synopsis. J Autoimmun. 2017;80:10-27.

8. Frésard A, Gagneux-Brunon A, Lucht F, BotelhoNevers E, Launay O. Immunization of HIV-infected adult patients - French recommendations. Hum Vaccin Immunother. 2016;12:2729-41.

9. Rahier JF, Magro F, Abreu C, et al. Second European evidence-based consensus on the prevention, diagnosis and management of opportunistic infections in inflammatory bowel disease. J Crohns Colitis. 2014;8:443-68.

10. Wasan SK, Baker SE, Skolnik PR, Farraye FA. A practical guide to vaccinating the inflammatory bowel disease patient. Am J Gastroenterol. 2010;105:1231-8.
11. Hilgendorf I, Freund M, Jilg W, et al. Vaccination of allogeneic haematopoietic stem cell transplant recipients: report from the international consensus conference on clinical practice in chronic GVHD. Vaccine. 2011;29:2825-33.

12. Davies JM, Lewis MP, Wimperis J, Rafi I, Ladhani S, Bolton-Maggs PH. Review of guidelines for the prevention and treatment of infection in patients with an absent or dysfunctional spleen. Br J Haematol. 2011;155:308-17.

13. Centers for Disease Control and Prevention (CDC). COVID-19 vaccines website. https://www.cdc.gov/ coronavirus/2019-ncov/vaccines/index.html. Accessed 31 Dec 2020.

14. Jeannet R, Daix T, Formento E, Feuillard J, François B. Severe COVID-19 is associated with deep and sustained multifaceted cellular immunosuppression. Int Care Med. 2020;46:1769-71.

15. Chinen J, Shearer WT. Secondary immunodeficiencies, including HIV infection. J Allergy Clin Immunol. 2010;125(2 Suppl 2):S195-203.

16. Axelrod H, Adams M. Biologic agents and secondary immune deficiency. Pediatr Clin North Am. 2019;66(5):1007-20.

17. Bagatini MD, Cardoso AM, Reschke CR, Carvalho FB. Immune system and chronic diseases 2018. J Immunol Res. 2018;2018:8653572.

18. Geerlings SE, Hoepelman AIM. Immune dysfunction in patients with diabetes mellitus (DM). FEMS Immunol Med Microbiol. 1999;26:259-65.

19. Borleffs JC, Schuurman HJ, Vrehen HM, Van Schaik $\mathrm{M}$, Bast EJ. In vitro and in vivo measurement of cellmediated immunity in patients with HIV-1 infection. Scand J Immunol. 1993;37:634-6.

20. Bonnave C, Mertens D, Peetermans W, et al. Adult vaccination for pneumococcal disease: a comparison of the national guidelines in Europe. Eur J Clin Microbiol Infect Dis. 2019;38:785-91.

21. Kennedy LB, Li Z, Savani BN, Ljungman P. Measuring immune response to commonly used vaccinations in adult recipients of allogeneic hematopoietic cell transplantation. Biol Blood Marrow Transplant. 2017;23(10):1614-21.

22. van Aalst M, Langedijk AC, Spijker R, de Bree GJ, Grobusch MP, Goorhuis A. The effect of immunosuppressive agents on immunogenicity of pneumococcal vaccination: a systematic review and meta-analysis. Vaccine. 2018;36(39):5832-45.

23. Karlsson J, Roalfe L, Hogevik H, et al. Poor correlation between pneumococcal IgG and IgM titers and 
opsonophagocytic activity in vaccinated patients with multiple myeloma and Waldenstrom's macroglobulinemia. Clin Vaccine Immunol. 2016;23:379-85.

24. Robertson JD, Nagesh K, Jowitt SN, et al. Immunogenicity of vaccination against influenza, Streptococcus pneumoniae and Haemophilus influenzae type $\mathrm{b}$ in patients with multiple myeloma. $\mathrm{Br} \mathrm{J}$ Cancer. 2000;82:1261-5.

25. Kunisaki KM, Janoff EM. Influenza in immunosuppressed populations: a review of infection frequency, morbidity, mortality, and vaccine responses. Lancet Infect Dis. 2009;9(8):493-504.

26. Engelhard D, Nagler A, Hardan I, et al. Antibody response to a two-dose regimen of influenza vaccine in allogeneic T cell-depleted and autologous BMT recipients. Bone Marrow Transplant. 1993;11:1.

27. Jaffe D, Papadopoulos EB, Young JW, et al. Immunogenicity of recombinant hepatitis $B$ vaccine $(\mathrm{rHBV})$ in recipients of unrelated or related allogeneic hematopoietic cell (HC) transplants. Blood. 2006;108:2470-5.

28. Renaud L, Schraen S, Fouquet G, et al. Response to pneumococcal vaccination in multiple myeloma. Cancer Med. 2019;8(8):3822-30.

29. Eckerle I, Rosenberger KD, Zwahlen M, Junghanss T. Serologic vaccination response after solid organ transplantation: a systematic review. PLoS One. 2013;8(2):e56974.

30. Mahler MB, Taur Y, Jean R, Kernan NA, Prockop SE, Small TN. Safety and immunogenicity of the tetravalent protein-conjugated meningococcal vaccine (MCV4) in recipients of related and unrelated allogeneic stem cell transplantation (alloHCT). Biol Blood Marrow Transpl. 2012;18:145-9.

31. van der Velden AM, Mulder AH, Hartkamp A, Diepersloot RJ, van Velzen-Blad H, Biesma DH. Influenza virus vaccination and booster in B-cell chronic lymphocytic leukaemia patients. Eur J Intern Med. 2001;12:420-4.

32. Pasiarski M, Rolinski J, Grywalska E, et al. Antibody and plasmablast response to 13-valent pneumococcal conjugate vaccine in chronic lymphocytic leukemia patients-preliminary report. PLoS One. 2014;9:e114966.

33. Rapezzi D, Sticchi L, Racchi O, Mangerini R, Ferraris AM, Gaetani GF. Influenza vaccine in chronic lymphoproliferative disorders and multiple myeloma. Eur J Haematol. 2003;70:225-30.
34. Carrera E, Manzano R, Garrido E. Efficacy of the vaccination in inflammatory bowel disease. World J Gastroenterol. 2013;19(9):1349-53.

35. Melmed GY, Agarwal N, Frenck RW, et al. Immunosuppression impairs response to pneumococcal polysaccharide vaccination in patients with inflammatory bowel disease. Am J Gastroenterol. 2010;105(1):148-54.

36. Chang JY, Jung SA, Moon CM, Kim SE, Jung HK, Shim KN. Response to hepatitis B vaccination in patients with inflammatory bowel disease: a prospective observational study in Korea. Intest Res. 2018;16(4):599-608.

37. Nunes MC, Madhi SA. Safety, immunogenicity and efficacy of pneumococcal conjugate vaccine in HIVinfected individuals. Hum Vaccin Immunother. 2012;8(2):161-73.

38. Kroon FP, van Dissel JT, Labadie J, van Loon AM, van Furth R. Antibody response to diphtheria, tetanus, and poliomyelitis vaccines in relation to the number of $\mathrm{CD} 4+\mathrm{T}$ lymphocytes in adults infected with human immunodeficiency virus. Clin Infect Dis. 1995;21(5):1197-203.

39. Eibl N, Spatz M, Fischer GF, et al. Impaired primary immune response in type- 1 diabetes: results from a controlled vaccination study. Clin Immunol. 2002;103:249-59.

40. Zhuang WH, Wang YP. Analysis of the immunity effects after enhanced hepatitis B vaccination on patients with lymphoma. Leuk Lymphoma. 2020;61(2):357-63.

41. Nagler A, Ilan Y, Adler R, et al. Successful immunization of autologous bone marrow transplantation recipients against hepatitis $B$ virus by active vaccination. Bone Marrow Transpl. 1995;15:475-8.

42. Rosado MM, Gesualdo F, Marcellini V, et al. Preserved antibody levels and loss of memory B cells against pneumococcus and tetanus after splenectomy: tailoring better vaccination strategies. Eur J Immunol. 2013;43(10):2659-70.

43. Ljungman P, Wiklund-Hammarsten M, Duraj V, et al. Response to tetanus toxoid immunization after allogeneic bone marrow transplantation. J Infect Dis. 1990;162(2):496-500.

44. Inaba H, Hartford CM, Pei D, et al. Longitudinal analysis of antibody response to immunization in paediatric survivors after allogeneic haematopoietic stem cell transplantation. $\mathrm{Br} \mathrm{J}$ Haematol. 2012;156(1):109-17.

45. Zlamy M, Elias J, Vogel U, et al. Immunogenicity of conjugate meningococcus $\mathrm{C}$ vaccine in pediatric 
solid organ transplant recipients. Vaccine. 2011;29: 6163-6.

46. Bonilla FA. Update: Vaccines in primary immunodeficiency. J Allergy Clin Immunol. 2018;141: 474-81.

47. Centers for Disease Control and Prevention. Vaccine recommendations and guidelines of the ACIP. https://www.cdc.gov/vaccines/hcp/acip-recs/ general-recs/immunocompetence.html. Accessed 15 Sept 2020.

48. Government of Canada. Canadian immunization guide: part 3 - vaccination of specific populations. http://www.phac-aspc.gc.ca/publicat/cig-gci/p03eng.php. Accessed 31 July 2020.

49. Australian Technical Advisory Group on Immunisation. The Australian Immunisation Handbook 10th Edition. http://www.immunise.health.gov.au/ internet/immunise/publishing.nsf/Content/ Handbook10-home. Accessed 31 July 2020.

50. Westerink MA, Schroeder HW Jr, Nahm MH. Immune responses to pneumococcal vaccines in children and adults: rationale for age-specific vaccination. Aging Dis. 2012;3:51-67.

51. Papadatou I, Spoulou V. Pneumococcal vaccination in high-risk individuals: are we doing it right? Clin Vaccine Immunol. 2016;23(5):388-95.

52. Käyhty H, Eskola J. New vaccines for the prevention of pneumococcal infections. Emerg Infect Dis. 1996;2(4):289-98.

53. Clutterbuck EA, Lazarus R, Yu L, et al. Pneumococcal conjugate and plain polysaccharide vaccines have divergent effects on antigen-specific $B$ cells. J Infect Dis. 2012;205:1408-16.

54. Kobayashi M. MMWR Morb Mortal Wkly Rep. 2015;64:944-7. https://www.cdc.gov/mmwr/ preview/mmwrhtml/mm6434a4.htm. Accessed 16 May 2020.

55. Bilukha OO, Rosenstein N. Prevention and control of meningococcal disease. Recommendations of the Advisory Committee on Immunization Practices (ACIP). MMWR Recomm Rep. 2005;54(RR-7):1-21.

56. Haut Conseil de la santé publique. Vaccinations for immunocompromised and asplenic patients. Recommendations, second edition, December 2014. [French language]. http://www.hcsp.fr/explore.cgi/ avisrapportsdomaine. Accessed 16 May 2020.

57. Folaranmi T, Rubin L, Martin SW, Patel M, MacNeil JR. Use of serogroup B meningococcal vaccines in persons aged $>/=10$ years at increased risk for serogroup B meningococcal disease: recommendations of the Advisory Committee on Immunization Practices, 2015. MMWR Morb Mortal Wkly Rep. 2015;64(22):608-12.

58. MacNeil JR, Rubin L, Folaranmi T, Ortega-Sanchez IR, Patel M, Martin SW. Use of serogroup B meningococcal vaccines in adolescents and young adults: recommendations of the Advisory Committee on Immunization Practices, 2015. MMWR Morb Mortal Wkly Rep. 2015;64(41):1171-6.

59. Osterholm MT, Kelley NS, Sommer A, Belongia EA. Efficacy and effectiveness of influenza vaccines: a systematic review and metaanalysis. Lancet Infect Dis. 2012;12:36-44.

60. Grohskopf LA, Alyanak E, Broder KR, Walter EB, Fry AM, Jernigan DB. MMWR Recomm Rep 2019;68: 1-17. https://www.cdc.gov/mmwr/volumes/68/rr/ pdfs/rr6803-H.pdf. Accessed 30 June 2020.

61. Bosaeed M, Kumar D. Seasonal influenza vaccine in immunocompromised persons. Hum Vacc Immunother. 2018;14:1311-22.

62. Gueller S, Allwinn R, Mousset S, et al. Enhanced immune response after a second dose of an ASO3adjuvanted $\mathrm{H} 1 \mathrm{~N} 1$ influenza $\mathrm{A}$ vaccine inpatients after hematopoietic stem cell transplantation. Biol Blood Marrow Transpl. 2011;17:1546-50.

63. Di Sabatino A, Carsetti R, Corazza GR. Postsplenectomy and hyposplenic states. Lancet. 2011;378:86-97.

64. Brown EJ, Hosea SW, Frank MM. The role of the spleen in experimental pneumococcal bacteremia. J Clin Invest. 1981;67:975-82.

65. Styrt B. Infection associated with asplenia: risks, mechanisms, and prevention. Am J Med. 1990;88: $33 \mathrm{~N}-42 \mathrm{~N}$.

66. Rubin LG, Schaffner W. Care of the asplenic patient. N Engl J Med. 2014;371:349-56.

67. Breukels MA, Zandvoort A, van Den Dobbelsteen GP, et al. Pneumococcal conjugate vaccines overcome splenic dependency of antibody response to pneumococcal polysaccharides. Infect Immun. 2001;69:7583-7.

68. Balmer $\mathrm{P}$, Falconer $\mathrm{M}$, McDonald $\mathrm{P}$, et al. Immune response to meningococcal serogroup $\mathrm{C}$ conjugate vaccine in asplenic individuals. Infect Immun. 2004;72(1):332-7.

69. Omrani AS, Almaghrabi RS. Complications of hematopoietic stem cell transplantation: bacterial infections. Hematol Oncol Stem Cell Ther. 2017;10: 228-32. 
70. Ljungman P, Cordonnier C, Einsele H, Jand AL. Vaccination of hematopoietic cell transplant recipients. Bone Marrow Transplantation. 2009;44: 521-6.

71. Small TN, Cowan MJ. Immunization of hematopoietic stem cell transplant recipients against vaccine-preventable diseases. Expert Rev Clin Immunol. 2011;7:193-203.

72. L'Huillier AG, Deepali K. Immunizations in solid organ and hematopoeitic stem cell transplant patients: a comprehensive review. Hum Vaccin Immunother. 2015;11:2852-63.

73. Cordonnier C, Labopin M, Robin C, et al. Longterm persistence of the immune response to antipneumococcal vaccines after Allo-SCT: 10-year follow-up of the EBMT-IDWP01 trial. Bone Marrow Transplant. 2015;50:978-83.

74. Parkkali T, Kayhty H, Lehtonen H, et al. Tetravalent meningococcal polysaccharide vaccine is immunogenic in adult allogeneic BMT recipients. Bone Marrow Transplant. 2001;27:79-84.

75. Hoffman R, Benz EJ, Silberstein LE, Heslop HE, Weitz JI, Anastasi J, Salama M, editors. Hematology: basic principles and practice. Chapter 89. 7th Revised Edition Philadelphia: Elsevier; 2017.

76. Kaplan B, Kopyltsova Y, Khokhar A, Lam F, Bonagura V. Rituximab and immune deficiency: case series and review of the literature. J Allergy Clin Immunol Pract. 2014;2:594-600.

77. Croce E, Hatz C, Jonker EF, Visser LG, Jaeger VK, Buhler S. Safety of live vaccinations on immunosuppressive therapy in patients with immune-mediated inflammatory diseases, solid organ transplantation or after bone-marrow transplantation-a systematic review of randomized trials, observational studies and case reports. Vaccine. 2017;35:1216-26.

78. Sinisalo M, Aittoniemi J, Käyhty H, Vilpo J. Vaccination against infections in chronic lymphocytic leukemia. Leuk Lymphoma. 2003;44:649-52.

79. Karlsson J, Hogevik H, Andersson K, Roshani L, Andrasson B, Wenners C. Pneumococcal vaccine responses in elderly patients with multiple myeloma, Waldenstrom's macroglobulinemia, and monoclonal gammopathy of undetermined significance. Trials Vaccinol. 2013;2(suppl C):31-8.

80. de Lavallade H, Garland P, Sekine T, et al. Repeated vaccination is required to optimize seroprotection against $\mathrm{H} 1 \mathrm{~N} 1$ in the immunocompromised host. Haematologica. 2011;96:307-14.
81. Aberg JA, Gallant JE, Ghanem KG, Emmanuel P, Zingman BS, Horberg MA. Primary care guidelines for the management of persons infected with HIV: 2013 update by the HIV medicine association of the Infectious Diseases Society of America. Clin Infect Dis. 2014;58(1):e1.

82. Panel on Antiretroviral Guidelines for Adults and Adolescents. Guidelines for the use of antiretroviral agents in adults and adolescents with HIV. Department of Health and Human Services (DHHS). 2019 http://aidsinfo.nih.gov/contentfiles/lvguidelines/ AdultandAdolescentGL.pdf. Accessed 20 May 2020.

83. Geretti AM, Brook G, Cameron C, et al. British HIV Association guidelines for immunization of HIVinfected adults 2008, HIV Med. 2008;9:795-848.

84. Moscicki AB, Karalius B, Tassiopoulos K, Yao TJ, Jacobson DL, Patel K. Human papillomavirus antibody levels and quadrivalent vaccine clinical effectiveness in perinatally human immunodeficiency virus-infected and exposed, uninfected youth. Clin Infect Dis. 2019;69:1183-91.

85. Denny L, Hendricks B, Gordon C, Thomas F, Hezareh M, Dobbelaere K. Safety and immunogenicity of the HPV-16/18 AS04-adjuvanted vaccine in HIV-positive women in South Africa: a partiallyblind randomised placebo-controlled study. Vaccine. 2013;31:5745-53.

86. Lacey CJ. HPV vaccination in HIV infection. Papillomavirus Res. 2019;8:100174.

87. Launay O, Grabar S, Gordien E, et al. Immunological efficacy of a three dose schedule of hepatitis A vaccine in HIV-infected adults: HEPAVAC study. J Acquir Immune Defic Syndr. 2008;49:272-5.

88. Atashili J, Kalilani L, Adimora AA. Efficacy and clinical effectiveness of influenza vaccines in HIVinfected individuals: a meta-analysis. BMC Infect Dis. 2006;6:138.

89. Anema A, Mills E, Montaner J, Brownstein JS, Cooper C. Efficacy of influenza vaccination in HIV positive patients: a systematic review and metaanalysis. HIV Med. 2008;9:57-61.

90. Chakvetadze C, Bani-Sadr F, Le Pendeven C, et al. Serologic response to hepatitis $B$ vaccination in HIV-Infected patients with isolated positivity for antibodies to hepatitis B core antigen. Clin Infect Dis. 2010;15(50):1184-6.

91. Crum-Cianflone NF, Wallace MR. Vaccination in HIV-infected adults. AIDS Patient Care STDS. 2014;28:397-410.

92. Melmed GY, Ippoliti AF, Papadakis KA, et al. Patients with inflammatory bowel disease are at risk 
for vaccine-preventable illnesses. Am J Gastroenterol. 2006;101:1834-40.

93. Loras C, Saro C, Gonzalez-Huix F, et al. Prevalence and factors related to hepatitis $B$ and $C$ in inflammatory bowel disease patients in Spain: a nationwide, multicenter study. Am J Gastroenterol. 2009; 104:57-63.

94. Malhi G, Rumman A, Thanabalan R, et al. Vaccination in inflammatory bowel disease patients: attitudes, knowledge, and uptake. J Crohns Colitis. 2015;9:439-44.

95. Farraye FA, Melmed GY, Lichtenstein GR, Kane SV. ACG Clinical Guideline: preventive care in inflammatory bowel disease. Am J Gastroenterol. 2017;112:241-58.

96. Long MD, Gulati A, Wohl D, et al. Immunizations in paediatric and adult patients with inflammatory bowel disease: a practical case-based approach. Inflamm Bowel Dis. 2015;21:1993-2003.

97. Kim DK, Bridges CB, Harriman KH, et al. Advisory committee on immunization practices recommended immunization schedule for adults aged 19 years or older: United States, 2016. Ann Intern Med. 2016;164:184-94.

98. Sands BE, Cuffari C, Katz J, et al. Guidelines for immunizations in patients with inflammatory bowel disease. Inflamm Bowel Dis. 2004;10:677-92.

99. Agarwal N, Ollington K, Kaneshiro M, et al. Are immunosuppressive medications associated with decreased responses to routine immunizations? A systematic review. Vaccine. 2012;30:1413-24.

100. Nguyen DL, Nguyen ET, Bechtold ML. Effect of immunosuppressive therapies for the treatment of inflammatory bowel disease on response to routine vaccinations: a meta-analysis. Dig Dis Sci. 2015;60: 2446-53.

101. Wyant T, Leach T, Sankoh S, et al. Vedolizumab affects antibody responses to immunization selectively in the gastrointestinal tract: randomized controlled trial results. Gut. 2015;64:77-83.

102. Gisbert JP, Chaparro M, Esteve M. Review article: prevention and management of hepatitis $B$ and $C$ infection in patients with inflammatory bowel disease. Aliment Pharmacol Ther. 2011;33:619-33.

103. Stobaugh DJ, Deepak P, Ehrenpreis ED. Hospitalizations for vaccine preventable pneumonias in patients with inflammatory bowel disease: a 6-year analysis of the Nationwide Inpatient Sample. Clin Exp Gastroenterol. 2013;6:43-9.
104. Vedolizumab (ENTYVIO) package insert. https:// www.accessdata.fda.gov/drugsatfda_docs/label/ 2014/125476s000lbl.pdf. Accessed 31 July 2020.

105. Manser CN, Maillard MH, Rogler G, Schreiner P, Rieder F, Bühler S. Vaccination in patients with inflammatory bowel diseases. Digestion. 2020;101(Suppl 1):58-68.

106. Gupta G, Lautenbach E, Lewis JD. Incidence and risk factors for herpes zoster among patients with inflammatory bowel disease. Clin Gastroenterol Hepatol. 2006;4:1483-90.

107. Winthrop KL, Curtis JR, Lindsey S, et al. Herpes zoster and tofacitinib: clinical outcomes and the risk of concomitant therapy. Arthritis Rheumatol. 2017;69:1960-8.

108. Colombel JF. Herpes zoster in patients receiving JAK inhibitors for ulcerative colitis: mechanism, epidemiology, management, and prevention. Inflamm Bowel Dis. 2018;24(10):2173-82.

109. Long MD, Martin C, Sandler RS, Kappelman MD. Increased risk of herpes zoster among 108604 patients with inflammatory bowel disease. Aliment Pharmacol Ther. 2013;37:420-9.

110. Khan N, Shah Y, Trivedi C, Lewis JD. Safety of herpes zoster vaccination among inflammatory bowel disease patients being treated with anti-TNF medications. Aliment Pharmacol Ther. 2017;46:668-72.

111. Manuel O, Humar A, Chen MH, Chernenko S, Singer LG, Cobos I, Kumar D. Immunogenicity and safety of an intradermal boosting strategy for vaccination against influenza in lung transplant recipients. Am J Transplant. 2007;7:2567-72.

112. Le Corre N, Thibault F, Pouteil Noble C, et al. Effect of two injections of non-adjuvanted influenza A H1N1pdm2009 vaccine in renal transplant recipients: INSERM C09- TRANSFLUVAC trial. Vaccine. 2012;30:7522-8.

113. Hojsak I, Avitzur Y, Mor E, et al. Antibody response to influenza vaccine in pediatric liver transplant recipients. Pediatr Infect Dis J. 2011;30(6):491-4.

114. Dooling KL, Guo A, Patel M, et al. Recommendations of the Advisory Committee on Immunization Practices for Use of Herpes Zoster Vaccines. MMWR Morb Mortal Wkly Rep. 2018;67:103-8.

115. Esposito S, Bruno C, Berardinelli A, et al. Vaccination recommendations for patients with neuromuscular disease. Vaccine. 2014;32(45):5893-900.

116. Esposito S, Passera S. Vaccination in patients with disorders of the muscle and neuromuscular junction. Expert Rev Vaccines. 2013;11:1341-9. 
117. Csuka D, Czirják L, Hóbor R, et al. Effective humoral immunity against diphtheria and tetanus in patients with systemic lupus erythematosus or myasthenia gravis. Mol Immunol. 2013;54:453-6.

118. Seminog OO, Goldacre MJ. Risk of pneumonia and pneumococcal disease in people hospitalized with diabetes mellitus: English record-linkage studies. Diabet Med. 2013;30:1412-9.

119. Torres A, Blasi F, Dartois N, Akova M. Which individuals are at increased risk of pneumococcal disease and why? Impact of COPD, asthma, smoking, diabetes, and/or chronic heart disease on community-acquired pneumonia and invasive pneumococcal disease. Thorax. 2015;70:984-9.

120. Hak E, Buskens E, van Essen GA, et al. Clinical effectiveness of influenza vaccination in persons younger than 65 years with high-risk medical conditions: the PRISMA study. Arch Intern Med. 2005; 165:274-80.

121. Loeb M, Dokainish H, Dans A, et al. Randomized controlled trial of influenza vaccine in patients with heart failure to reduce adverse vascular events (IVVE): Rationale and design. Am Heart J. 2019;212: 36-44.

122. Nichol KL, Nordin J, Mullooly J, Lask R, Fillbrandt $\mathrm{K}$, Iwane $\mathrm{M}$. Influenza vaccination and reduction in hospitalizations for cardiac disease and stroke among the elderly. N Engl J Med. 2003;348(14): 1322-32.

123. Husein N, Chetty A. Diabetes Canada Clinical Practice Guidelines Expert Committee, Influenza, Pneumococcal, Hepatitis B and Herpes Zoster Vaccinations. Can J Diabetes. 2018;42:S142-4.

124. Papagianni M, Metallidis S, Tziomalos K. Herpes zoster and diabetes mellitus: a review. Diabetes Ther. 2018;9:545-50.

125. Poole PJ, Chacko E, Wood-Baker RW, Cates CJ. Influenza vaccine for patients with chronic obstructive pulmonary disease. Cochrane Database Syst Rev. 2006(1):CD002733.

126. Malfroot A, Adam G, Ciofu O, et al. Immunisation in the current management of cystic fibrosis patients. J Cyst Fibros. 2005;4:77-87.

127. Slifka MK, Amanna IJ. Role of multivalency and antigenic threshold in generating protective antibody responses. Front Immunol. 2019;10:956.

128. Garland SM, Brotherton JML, Moscicki AB, et al. HPV vaccination of immunocompromised hosts. Papillomavirus Res. 2017;4:35-8.

129. Mullane KM, Morrison VA, Camacho LH, et al. V212 Protocol 011 Trial Team. Safety and efficacy of inactivated varicella zoster virus vaccine in immunocompromised patients with malignancies: a two-arm, randomised, double-blind, phase 3 trial. Lancet Infect Dis. 2019;19:1001-1012

130. Boeckh MJ, Arvin AM, Mullane KM, et al. V212 Protocol 001 Trial Group and V212 Protocol 011 Trial Group. Immunogenicity of inactivated varicella zoster vaccine in autologous hematopoietic stem cell transplant recipients and patients with solid or hematologic cancer. Open Forum Infect Dis. 2020;7(7):ofaa172

131. CDC. COVID-19 vaccines website. https://www. cdc.gov/coronavirus/2019-ncov/vaccines/index. html. Accessed 10 Jan 2021.

132. Oliver S, Gargano J, Marin M, et al. The Advisory Committee on Immunization Practices' Interim Recommendation for Use of Pfizer-BioNTech COVID-19 Vaccine - United States, December 2020. MMWR Morb Mortal Wkly Rep. 2020;69: 1922-4.

133. Oliver S, Gargano J, Marin M, et al. The Advisory Committee on Immunization Practices' Interim Recommendation for Use of Moderna COVID-19 Vaccine - United States, December 2020. MMWR Morb Mortal Wkly Rep. 2021;69:1653-6. 